\title{
The Effects of Different Irrigation Scheduling Approaches on Seed Yield and Water Use Efficiencies of Cotton
}

\author{
Safiye Pınar Tunalı, ${ }^{1, a,}$, Talih Gürbüz ${ }^{2, b}$, Necdet Dağdelen ${ }^{1, c}$, Selin Akçay ${ }^{1, d}$ \\ ${ }^{1}$ Department of Biosystem Engineering, Faculty of Agriculture, Aydin Adnan Menderes University, 09100 Aydin, Turkey \\ ${ }^{2}$ Koçarll Vocational College, Aydın Adnan Menderes University 09100, Aydın, Turkey
}

*Corresponding author

A R T I C LE IN F O

Research Article

Received : 03/04/2021

Accepted : 24/06/2021 \begin{abstract}
A B S T R A C T
This study was conducted in the Aegean region conditions of Turkey in 2020. It was carried out on May-505, a local cotton variety. The study examined the variation of seed yield, water use efficiency (WUE), and irrigation water use efficiency (IWUE) of cotton with different irrigation programs and water levels. The field trial, which was designed as two factors and three replications, was designed according to the randomized complete block trial design. Four different irrigation levels (IL) (100\%, $67 \%, 33 \%$, and $0 \%$ ) and two different irrigation scheduling approaches (gravimetric and pan evaporation) were investigated in the study. Seasonal water use values in treatments varied between $215(0 \%)$ and $746(100 \%$ - Pan evaporation approach) mm during the production period. The average yield values obtained with irrigation levels, which have essential effects on cotton seed yield, are listed as follows; $2057 \mathrm{~kg} \mathrm{ha}^{-1}$ (IL-0\%), $3471 \mathrm{~kg} \mathrm{ha}^{-1}$ (IL-33\%), $3771 \mathrm{~kg} \mathrm{ha}^{-1}$ (IL-67\%), and $5083 \mathrm{~kg}$ $\mathrm{ha}^{-1}$ (IL-100\%). It was determined pan evaporation applications performed higher yields than gravimetric applications. WUE values were between $0.63-1.04 \mathrm{~kg} \mathrm{~m}^{-3}$. The gravimetric method's yield response factor $\left(\mathrm{k}_{\mathrm{y}}\right)$ was 0.73 , and the pan evaporation method's yield response factor $\left(\mathrm{k}_{\mathrm{y}}\right)$ was 0.89. These results show that cotton is tolerant of water stress. In conclusion, although the pan evaporation approach with $100 \%$ treatment is suggested for cotton production in the parts of the Aegean region within the semi-arid climate zone, while water resources are sufficient. When the results are evaluated in terms of seed cotton yield for a deficit irrigation strategy, IL-67\% treatment with a gravimetric approach can be used.
\end{abstract}

Cotton

Drip irrigation

Irrigation levels

Aegean region

Yield response factor

Türk Tarım - Gıda Bilim ve Teknoloji Dergisi, 9(8): 1530-1536, 2021

\section{Farklı Sulama Programlama Yaklaşımlarının Pamukta Verim ve Su Kullanım Randımanları Üzerine Etkileri}

\begin{tabular}{|c|c|}
\hline M A K A L E B İ L G İ S İ & Ö Z \\
\hline $\begin{array}{l}\text { Anahtar Kelimeler: } \\
\text { Pamuk } \\
\text { Damla sulama } \\
\text { Sulama düzeyi } \\
\text { Ege bölgesi } \\
\text { Verim azalma oranı }\end{array}$ & 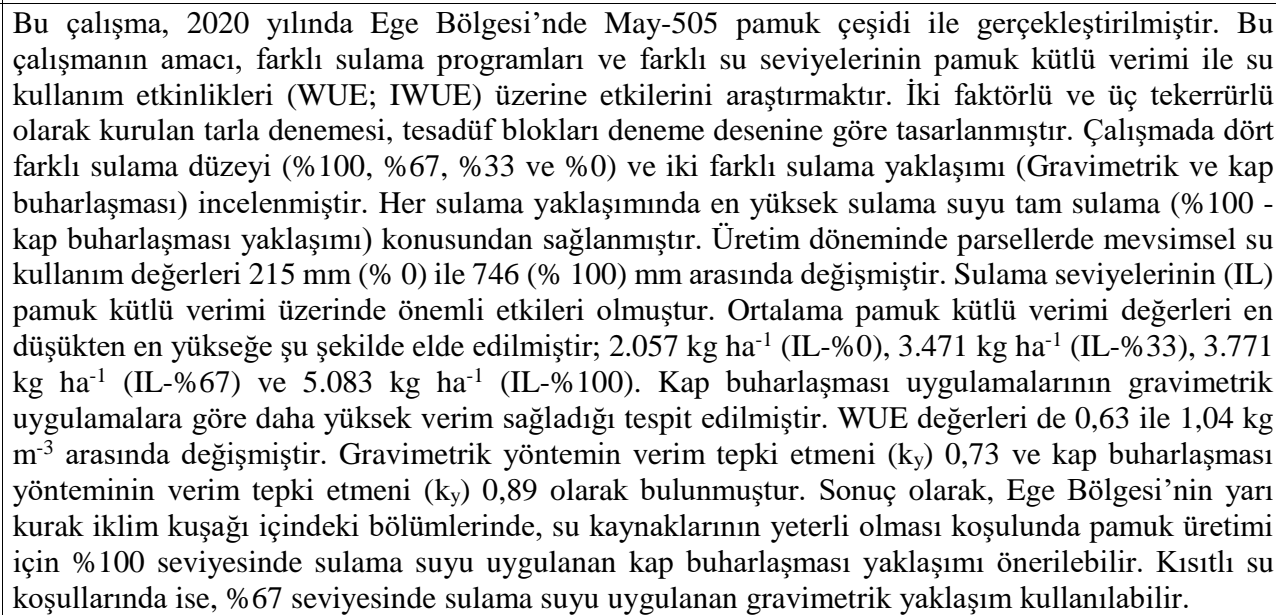 \\
\hline
\end{tabular}




\section{Introduction}

The amount and distribution of rainfall in all cottonproducing areas in the Aegean region are one of Turkey's most important agricultural regions are inadequate. Besides, the decrease in groundwater resources and high costs of energy also negatively affect irrigated cotton production. In Turkey's near future, particularly for some products, urgent measures should be taken to avoid water scarcity problems. Limited water resources necessitate efforts to make radical changes in irrigation management and to encourage deficit irrigation practices. Also, it is essential to ensure that producers choose irrigation methods with higher irrigation water efficiency methods (such as drip irrigation, subsurface drip irrigation (SDI), sprinkler irrigation, and low-energy precision applicators (LEPA)) (Simsek et al., 2004). Turkey's seed cotton production meets approximately $44 \%$ of the needs of its domestic market. In Turkey, among the first 11 countries made of cotton production globally, in the 2018/2019 season, seed cotton acreage, crop production, and average cotton lint yield were determined 508000 ha, 988000 tonnes, and $1944 \mathrm{~kg} \mathrm{ha}^{-1}$, respectively (Anonymous, 2019a). The decrease in groundwater resources due to climate change and the increase in industrial and domestic water consumption have led to a decrease in the amount of water available for agricultural production. Also, the effects of global warming are more and more being felt, and one of the most important of these is drought. Evaporation has a significant role in efficient water use, preparing irrigation programs, and agricultural water management (Yazar et al., 2002a; Panda et al., 2004). Pan evaporation has become a widely preferred method in irrigation planning because it is a method that farmers can easily apply, and pan evaporation has a close correlation with evapotranspiration (Kanber, 1984; Wang et al., 2009). As with many crops, irrigation in cotton is recommended by sprinkler and drip irrigation methods. It can be applied in various topographic and soil conditions and provides frequent and uniform water applications. Compared with furrow and sprinkler irrigation, although irrigated by drip irrigation in cotton yield and with higher water use efficiency values, surface irrigation is still preferred in Turkey (Çetin and Bilgel, 2002; Dagdelen et al., 2006). Mateos et al. (1991) reported that the drip irrigation method could be preferred because water use efficiency is $30 \%$ higher than the furrow irrigation method in limited water resource conditions.

Yazar et al. (2002b), in a study conducted in Turkey Southeastern Anatolia Region conditions, investigated the effects of different irrigation methods, levels, and intervals on yield of cotton. The researchers obtained the highest average cotton yield as $5850 \mathrm{~kg} \mathrm{ha}^{-1}$ from full irrigation (100\%) on land irrigated with drip irrigation at 6-day intervals. In a study evaluating seed cotton yield with different irrigation intervals in drip irrigation under Cukurova conditions, the maximum seed cotton yield was $4220 \mathrm{~kg} \mathrm{ha}^{-1}$, and seasonal water consumption was $511 \mathrm{~mm}$ in the parcel irrigated at five days intervals (Ertek and Kanber, 2001). Since the importance of using irrigation water effectively increases daily, it is necessary to prefer methods that will increase water use efficiency, such as drip and sprinkler irrigation (Sezen et al., 2004). Many studies have been obtained in favor of the drip irrigation method due to the high cotton yield and high WUE values (Mateos et al., 1991; Ertek and Kanber, 2001; Cetin and Bilgel, 2002; Yazar et al., 2002b; Karam et al., 2006; Ibragimov et al., 2007). Basal et al. (2009) investigated the effects of different water doses on water use efficiency, yield, yield components, and fiber quality in drip irrigation. They found that water use efficiency increased from 0.62 to $0.75 \mathrm{~kg} \mathrm{~m}^{-3}$ when the water rates decreased from $100 \%$ to $75 \%$. It was also found that raw cotton yield, the number of bolls, and the weight of cotton per boll fell in parallel with the irrigation level reduction. Dağdelen et al. (2009) investigated the effects of different water levels on water use efficiency and fiber quality parameters under drip irrigation methods in the Aegean region in 2004-2005. The authors reported that the water use efficiency varied between 0.76 and $0.98 \mathrm{~kg} \mathrm{~m}^{-3}$. The average cotton yield was between 2550 and $5760 \mathrm{~kg} \mathrm{ha}^{-1}$, and the average seasonal plant water consumption was between 256 and $753 \mathrm{~mm}$. In a study conducted on cotton under Syrian conditions to determine the effect of different irrigation rates on cotton yield, water use efficiency, and fiber quality, researchers found the average cotton yield between 2909 and $5090 \mathrm{~kg} \mathrm{ha}^{-1}$, and the plant water consumption ranged from 408 to $773 \mathrm{~mm}$ (Hussein et al., 2011). Also, the highest WUE value, $0.71 \mathrm{~kg} \mathrm{~m}^{-3}$, was obtained from the irrigation application of $80 \%$ of the soil water depletion. Erten and Dagdelen (2020) conducted a study to determine the effects of $0 \%, 25 \%, 50 \%, 75 \%$, and $100 \%$ irrigation levels with gravimetric approach on cotton yield using drip irrigation under Aydın-Turkey conditions. The researchers found average WUE and IWUE values varied between $0.747-1.120$ and $0.972-2.503 \mathrm{~kg} \mathrm{~m}^{-3}$, respectively.

The scarce of water is a critical problem in cotton production. Besides different drip irrigation levels, proper management, such as irrigation approaches should be studied by researchers. Therefore, limited irrigation water resources require significant changes in irrigation management or require water conservation practices. This study aimed to determine the effects of different irrigation scheduling approaches and irrigation levels on water use efficiency and seed cotton yield in cotton irrigated by drip irrigation method and select the most suitable irrigation program in cotton in semi-arid climatic conditions.

\section{Materials and Methods}

This research was carried out at Aydın Adnan Menderes University Agricultural Research Station in the 2020 production season. The research area is at $37^{0} 51^{\prime} \mathrm{N}$ latitude, $27^{\circ} 51^{\prime}$ 'E longitude, $56 \mathrm{~m}$ altitude, and is in the semi-arid climate zone. In the Lower Büyük Menderes Basin, where the research station is located, the Mediterranean climate prevails with hot and dry summers and cold and rainy winters. According to the long-term climate data, the total amount of precipitation in the basin is $657 \mathrm{~mm}$ year $^{-1}$. Climate data obtained during the production season (May - September / 2020) are given in Table 1 (Anonymous, 2019b). 
Table 1. Climatic variables for experimental site

\begin{tabular}{|c|c|c|c|c|}
\hline \multicolumn{5}{|c|}{$1970-2019$} \\
\hline Month & Temperature $\left({ }^{\circ} \mathrm{C}\right)$ & Relative Humidity (\%) & Rainfall (mm) & Evaporation (mm) \\
\hline May & 21 & 56.9 & 35.6 & 161.3 \\
\hline June & 26 & 49.2 & 16.6 & 222.1 \\
\hline July & 28.6 & 48.6 & 7.5 & 257.5 \\
\hline August & 27.6 & 52.9 & 5.3 & 231.6 \\
\hline September & 23.3 & 55.9 & 15.1 & 161.9 \\
\hline \multicolumn{5}{|c|}{2020} \\
\hline Month & Temperature $\left({ }^{\circ} \mathrm{C}\right)$ & Relative Humidity (\%) & Rainfall (mm) & Evaporation (mm) \\
\hline May & 22.1 & 54.9 & 33.3 & 175.2 \\
\hline June & 25.2 & 54.4 & 20.3 & 200.2 \\
\hline July & 29.9 & 47.8 & 0 & 272.6 \\
\hline August & 29.2 & 46.9 & 0 & 247.1 \\
\hline September & 26.9 & 54.7 & 0 & 182.8 \\
\hline
\end{tabular}

Table 2. Some physical characteristics of experimental site soils

\begin{tabular}{c|ccccc}
\hline $\begin{array}{c}\text { Soil depth } \\
(\mathrm{cm})\end{array}$ & $\begin{array}{c}\text { Soil } \\
\text { texture }\end{array}$ & $\begin{array}{c}\text { Bulk density } \\
\left(\mathrm{g} \mathrm{cm}^{-3}\right)\end{array}$ & $\begin{array}{c}\text { Field capacity } \\
(\%)^{*}\end{array}$ & $\begin{array}{c}\text { Wilting point } \\
(\%)^{*}\end{array}$ & $\begin{array}{c}\text { Available water holding } \\
\text { capacity }(\mathrm{mm})\end{array}$ \\
\hline $0-30$ & Sandy-Loam & 1.35 & 23.1 & 10.1 & 52.6 \\
$30-60$ & Sandy-Loam & 1.45 & 22.9 & 9.4 & 58.8 \\
$60-90$ & Sandy-Loam & 1.52 & 18.4 & 7.3 & 50.6 \\
$90-120$ & Sandy-Loam & 1.50 & 20.3 & 7.2 & 59.0 \\
\hline $0-120$ & & & & 221.0 \\
\hline
\end{tabular}

*on a dry weight basis

Table 3. Irrigation treatments examined in the research

\begin{tabular}{l|cc}
\hline Irrigation application methods & Irrigation Levels (\%) & Abbreviations \\
\hline \multirow{3}{*}{ Gravimetric } & 100 & $\mathrm{C}_{1}$ \\
& 67 & $\mathrm{C}_{2}$ \\
& 33 & $\mathrm{C}_{3}$ \\
& 0 & $\mathrm{C}_{4}$ \\
Pan evaporation & 100 & $\mathrm{D}_{1}$ \\
& 67 & $\mathrm{D}_{2}$ \\
\hline
\end{tabular}

When the climate data of long years in Table 1 are examined, it is seen that the average temperature was $25.3^{\circ} \mathrm{C}$ and the average relative humidity was $52.7 \%$. In addition, the total precipitation and evaporation amounts were measured as $80.10 \mathrm{~mm}$ and $1034.40 \mathrm{~mm}$, respectively. In the trial year, the average temperature was $26.7^{\circ} \mathrm{C}$ and the average relative humidity was $51.7 \%$. Also, the total precipitation and evaporation amounts were measured as $53.60 \mathrm{~mm}$ and $1077.90 \mathrm{~mm}$, respectively.

The soil series in the research area was Büyük Menderes Basin developed on alluvial materials (Aksoy et al., 1998). The experimental site's soil is classified as Entisols and Fluvisols-Regosols silty-clay-loam with relatively high water holding capacity. The soil texture, bulk density, field capacity, wilting point, and available water holding capacity values of each $30 \mathrm{~cm}$ layer of 0 $120 \mathrm{~cm}$ soil depth in the experimental area are given in Table 2.

Before starting the field experiment, $50 \mathrm{~kg} \mathrm{da}^{-1}$ compound fertilizer (containing $15 \%$ pure N, $15 \% \mathrm{P}$, and $15 \% \mathrm{~K})$ was applied to the planting area. The planting process was carried out on May 13, 2020, at $0.70 \times 0.20 \mathrm{~m}$ intervals, and the May-505 cotton variety was used. The required remaining portion of nitrogen was given by $40 \mathrm{~kg}$ $\mathrm{da}^{-1}$ before first irrigation.

The study, prepared as a randomized complete block design with three replications and two factors; four different irrigation levels $(100,67,33$, and $0 \%)$ and two different irrigation program techniques (gravimetric and pan evaporation) were investigated. There is $3 \mathrm{~m}$ space between each of the trial plots, and four cotton rows with $0.7 \mathrm{~m}$ intervals and $5 \mathrm{~m}$ lengths have been created within the plot. In the pan evaporation method, irrigation water was applied to $\mathrm{D}_{1}$ (control), $\mathrm{D}_{2}, \mathrm{D}_{3}$, and $\mathrm{D}_{4}$ treatments, respectively $100 \%, 67 \%, 33 \%$, and $0 \%$ of the 7 -day cumulative pan evaporation amounts measured from the class-A pan. In gravimetric method, irrigation water was applied when $50 \%$ of available water in the root zone $(0-$ $90 \mathrm{~cm}$ ) is consumed. Irrigation amount to $\mathrm{C}_{1}$ (control), $\mathrm{C}_{2}$, $\mathrm{C}_{3}$ and $\mathrm{C}_{4}$ treatments, were $100 \%, 67 \%, 33 \%$ and $0 \%$ of consumption, respectively. (Table 3 ).

Equation (1 and 2) was used to calculate the irrigation water amount for two approaches;

$$
\begin{aligned}
& \mathrm{V}=\mathrm{P} \times \mathrm{A} \times \mathrm{E}_{\mathrm{pan}} \times \mathrm{WL} \\
& \mathrm{I}=(\mathrm{FC}-\mathrm{AW}) / 100 \times \mathrm{yt}_{\mathrm{t}} \times \mathrm{D} \\
& \mathrm{V}=\mathrm{I} \times \mathrm{A} \times \mathrm{WL}
\end{aligned}
$$


Where $\mathrm{V}$ is the volume of irrigation water $(\mathrm{L}), \mathrm{P}$ percentage of wetted area (taken as $100 \%$ for row crops), A is plot area $\left(\mathrm{m}^{2}\right), \mathrm{E}_{\mathrm{pan}}$ is the amount of cumulative evaporation during a seven-day irrigation interval $(\mathrm{mm}), \mathrm{WL}$ represents irrigation levels $(0.33,0.67$ and 1.00), FC field capacity $(\mathrm{mm})$, AW available water in the soil within $90 \mathrm{~cm}$ depth before irrigation applications $(\mathrm{mm}), \gamma_{t}$ bulk density $(\mathrm{g}$ $\mathrm{cm}^{-3}$ ) and D effective root zone (mm). Class A pan, used to measure the evaporation, was placed next to the plots in the meteorology. The irrigation water required for the plots was obtained from the underground water source (deep well) in the experiment area, and the drip irrigation method was applied. Right next to the deep well, there is a control unit consisting of control valves, a screen filter with a capacity of $10 \mathrm{~L} \mathrm{~s}^{-1}$, manometers mounted at the inlet and outlet of each unit. $63 \mathrm{~mm}$ outer diameter PVC latch manifold pipes were used to transmit the water taken from the control unit to the parcels, and in the parcel, $16 \mathrm{~mm}$ diameter PE lateral pipes were placed along the plant rows. In the parcel, irrigation lines with $10 \mathrm{~m}$ operating pressure, $4 \mathrm{~L} \mathrm{~h}^{-1}$ discharge rate, $0.2 \mathrm{~m}$ dripper range, and $0.7 \mathrm{~m}$ lateral range were used to convey water in the parcel. Soil water balance equation (3) was used to determine crop water consumption of the treatments as follows (Heerman, 1985);

$$
\mathrm{ET}=\mathrm{R}+\mathrm{I}-\mathrm{D} \pm \Delta \mathrm{W}
$$

Where; ET is the crop water use $(\mathrm{mm}), R$ is the effective rainfall $(\mathrm{mm}), I$ is the irrigation amount $(\mathrm{mm}), D$ is the quantity of percolation ( $\mathrm{mm})$, and $\Delta W$ is the conversion of soil water storage in the measured soil depth.

The WUE values used in the study were obtained by dividing the yield values $\left(\mathrm{kg} \mathrm{ha}^{-1}\right)$ by the water use efficiency $(\mathrm{mm})$, and the IWUE values were obtained by dividing the yield values $\left(\mathrm{kg} \mathrm{ha}^{-1}\right)$ by the amount of irrigation water applied (mm) (Howell et al., 1990). Then, the Stewart model (Doorenbos and Kassam, 1986) was used to determine the relationship between water and yield for each irrigation program (Equation 4):

$$
1-(\mathrm{Ya} / \mathrm{Ym})=\mathrm{k}_{\mathrm{y}}(1-\mathrm{ETa} / \mathrm{ETm})
$$

Where; ETa is the actual seasonal crop water use-value (mm), ETm is the maximum seasonal crop water use-value (mm), $Y a$ is the corresponding actual yield $\left(\mathrm{kg} \mathrm{ha}^{-1}\right)$, and $\mathrm{Ym}$ is the corresponding maximum yield $\left(\mathrm{kg} \mathrm{ha}^{-1}\right)$.

The yield values used in the above equations were obtained by weighing the cotton harvested by hand from each parcel on October 16, 2020. Then, these yield values were subjected to variance analysis, and the differences between irrigation practices were determined. Besides, irrigation practices were compared and ranked using the least significant differences test (LSD). The significance level for the differences here was taken as $\mathrm{P}<0.05$. The TARIST program was used to make these calculations (Acikgoz et al., 1994).

\section{Results and Discussions}

The total amount of irrigation water given to the treatments, seasonal crop water consumption, WUE, and IWUE values for the production period are shown in Table 4. Irrigations were conducted seven times between July 9 and August 26, 2020. The total amount of irrigation water supplied to the treatments was between $177-550 \mathrm{~mm}$.

Seasonal plant water use values varied in connection with the irrigation water applied to the parcels and moisture at planting and harvest. Simultaneously, although it has a significant effect on plant water consumption, there was no rain in the growing season's experimental area. In parallel with the increase in irrigation levels in each application, water use values have also increased. Seasonal water use varied from $746 \mathrm{~mm} \mathrm{D}_{1}$ treatment (pan evaporation) to 215 $\mathrm{mm}$ in $\mathrm{D}_{4}$ treatment (rain-fed) plots in the production period and $719 \mathrm{~mm}$ in $\mathrm{C}_{1}$ (gravimetric) treatment to 215 $\mathrm{mm}$ in $\mathrm{C}_{4}$ treatment (rain-fed) plots. This was followed by $\mathrm{D}_{2}$ and $\mathrm{C}_{2}$ treatments, 572 and $553 \mathrm{~mm}$ in the growing season, respectively (Table 4). The highest seasonal water use values were obtained from treatments $D_{1}$ and $C_{1}$ control treatments $(100 \%)$ as $746 \mathrm{~mm}$ and $719 \mathrm{~mm}$, respectively. Similar to our findings, the seasonal water use value of 800 mm was obtained by Erten and Dagdelen (2020) under Aydın Plain conditions. Sezgin et al. (2001) and Dağdelen et al. (2006) obtained 899 and $855-882 \mathrm{~mm}$ of seasonal water consumption with furrow irrigation in the same region. Also, in similar studies with drip irrigation Dağdelen et al. (2009), Basal et al. (2009), Akcay and Dağdelen (2017) and Tunalı et al. (2020) obtained 265 $753,268-754,331-774$, and $305-723 \mathrm{~mm}$, respectively. Seasonal water consumption values obtained in studies conducted in different regions using the drip irrigation method are as follows: it was between $287-584 \mathrm{~mm}$ in Adana conditions (Unlu et al., 2011), between 410 - 725 $\mathrm{mm}$ in High Texas Plains in (Colaizzi et al., 2005), and around $738 \mathrm{~mm}$ in the conditions of the Bekaa Valley in Lebanon (Karam et al., 2006). When the results of the mentioned studies are examined, it can be said that they are in harmony with this study's results.

Table 4. Seed cotton yield and water use efficiency values as influenced by irrigation application methods and irrigation levels

\begin{tabular}{c|cccccc}
\hline $\begin{array}{c}\text { Irrigation } \\
\begin{array}{c}\text { application } \\
\text { methods }\end{array}\end{array}$ & $\begin{array}{c}\text { Irrigation } \\
\text { Levels }\end{array}$ & $\begin{array}{c}\text { Seed cotton } \\
\text { yield } \\
\left(\mathrm{kg} \mathrm{ha}^{-1}\right)\end{array}$ & $\begin{array}{c}\text { Irrigation } \\
\text { water applied } \\
(\mathrm{mm})\end{array}$ & $\begin{array}{c}\text { Water use } \\
(\mathrm{mm})\end{array}$ & $\begin{array}{c}\text { Water use } \\
\text { efficiency } \\
(\text { WUE })\left(\mathrm{kg} \mathrm{m}^{-3}\right)\end{array}$ & $\begin{array}{c}\text { Irrigation water use } \\
\text { efficiency } \\
(\text { IWUE })\left(\mathrm{kg} \mathrm{m}^{-3}\right)\end{array}$ \\
\hline \multirow{5}{*}{ Gravimetric } & $\mathrm{C} 1-100 \%$ & 4995 & 536 & 719 & 0.695 & 0.932 \\
& $\mathrm{C} 2-67 \%$ & 3943 & 359 & 553 & 0.713 & 1.098 \\
& $\mathrm{C} 3-33 \%$ & 3657 & 177 & 383 & 0.954 & 2.066 \\
\hline \multirow{3}{*}{ Pan } & $\mathrm{C} 4-0 \%$ & 2257 & - & 215 & 1.049 & 0.940 \\
evaporation & $\mathrm{D} 1-100 \%$ & 5171 & 550 & 746 & 0.693 & 0.977 \\
& $\mathrm{D} 2-67 \%$ & 3600 & 368 & 572 & 0.630 & 1.810 \\
& $\mathrm{D} 3-33 \%$ & 3286 & 181 & 392 & 0.838 & - \\
\hline
\end{tabular}


Table 5. Variance analysis of seed cotton yield influenced by different treatments and irrigation levels

\begin{tabular}{l|lc}
\hline & \multicolumn{2}{c}{ Seed cotton yield $\left(\mathrm{kg} \mathrm{ha}^{-1}\right)$} \\
\hline \multirow{2}{*}{ Treatment (T) } & Gravimetric & 3713 \\
& Pan & 3478 \\
\hline LSD $\% 5$ & & $5083^{\mathrm{a}}$ \\
\hline \multirow{2}{*}{ Irrigation Level (IL) } & $\% 100$ & $3771^{\mathrm{b}}$ \\
& $\% 67$ & $3471^{\mathrm{b}}$ \\
& $\% 33$ & $2057^{\mathrm{c}}$ \\
\hline LSD $\% 5$ & $\% 0$ & 72.527 \\
& & $\mathrm{~ns}$ \\
& $\mathrm{~T}$ & $* *$ \\
& $\mathrm{IL}$ & $\mathrm{ns}$ \\
\hline
\end{tabular}

$* \mathrm{P}<0.05 ; * * \mathrm{P}<0.01 ; \mathrm{ns}$ : not significant, In a column values with a common letter does not significantly differ from one another using LSD $\% 5$

Table 6. The comparison of WUE and IWUE values for different research

\begin{tabular}{l|ccc}
\hline \multicolumn{1}{c|}{ Sources } & Irrigation system & WUE $\left(\mathrm{kg} \mathrm{m}^{-3}\right)$ & IWUE $\left(\mathrm{kg} \mathrm{m}^{-3}\right)$ \\
\hline Our research & Drip & $0.69-1.04$ & $0.93-2.06$ \\
Ertek and Kanber (2001) & Drip & $0.58-0.62$ & $0.75-0.94$ \\
Yazar et al. (2002a) & Drip & $0.50-0.74$ & $0.60-0.81$ \\
Yazar et al. (2002b) & Lepa & $0.55-0.67$ & $0.58-0.77$ \\
Karam et al. (2006) & Drip & $0.80-1.30$ & - \\
Ibragimov et al. (2007) & Drip & $0.63-0.88$ & $0.82-1.12$ \\
Dagdelen et al. (2009) & Drip & $0.77-0.96$ & $0.82-1.44$ \\
Basal et al. (2009) & Drip & $0.62-0.85$ & $0.66-1.57$ \\
Akcay and Dagdelen (2017) & Drip & $0.83-1.26$ & $1.05-1.96$ \\
Dagdelen et al. (2019) & Drip & $0.73-1.13$ & $0.91-2.23$ \\
Erten and Dagdelen (2020) & Drip & $0.74-1.12$ & $0.97-2.50$ \\
\hline Tunali et al. (2020) & Drip & $0.83-1.19$ & $1.03-1.93$ \\
\hline
\end{tabular}

The response of seed cotton yield for different irrigation treatments is given in Table 5. When the results obtained were analyzed, it was shown that irrigation levels significantly affected cotton yield. No interaction was observed between irrigation practices (T) and irrigation levels (IL) for the parameters examined. Seed cotton yield had no significantly affected on irrigation applications (T). The gravimetric application resulted in higher efficiency than pan evaporation applications. It has been observed that cotton yield increases with irrigation water levels. When the irrigation levels (IL) were examined, three groups were formed during the year. The first group consisted of the $100 \%$ treatments where no water restriction had been applied in the whole growing season, treatments in which water had been applied at the $67 \%$ level were second. Treatments that had received water at the $33 \%$ level formed the last group. As the irrigation level increased, the cotton yield increased. Average yield values according to irrigation levels are as follows: in IL-100 5083 $\mathrm{kg} \mathrm{ha}^{-1}$, in IL-67 $3771 \mathrm{~kg} \mathrm{ha}^{-1}$, in IL-33 $3471 \mathrm{~kg} \mathrm{ha}^{-1}$ and IL-0 (based on rainfall) $2057 \mathrm{~kg} \mathrm{ha}^{-1}$. When the yield reduction ratio values between the irrigation levels are examined in the study, it was determined that there is a $59.6 \%$ difference in yield between the lowest and highest efficiency values. When the irrigation level decreased from $100 \%$ to $67 \%$, there was a $33 \%$ reduction in the water level; cotton yield decreased by $31.7 \%$. Similar results have been reported in many previous studies.

Dagdelen et al. (2005) obtained the highest cotton efficiency with the drip irrigation method in Aydin Region from full irrigation (100\%). They irrigated at eight-day intervals in the class A pan evaporation method. On the other hand, Yazar et al. (2002b) obtained the highest seed cotton yield $\left(5870 \mathrm{~kg} \mathrm{ha}^{-1}\right)$ in the Harran Plain from full irrigation (100\%), which they irrigated with the drip irrigation method with a six-day irrigation interval. Dagdelen et al. (2009) studied the drip irrigation method in western Turkey, found the average cotton yield $5760 \mathrm{~kg} \mathrm{ha}^{-1}$. In another study conducted under Aydin Plain conditions, the treatment with the highest average cotton yield was obtained from S1 (Carisma - V1) treatment with $6300 \mathrm{~kg}$ $\mathrm{ha}^{-1}$, and it was determined that the yield of Carisma-V1 variety was higher than the other varieties used in the study (Candia - V2 and Gloria - V3) (Dagdelen et al., 2019). Similar results were obtained by Erten and Dagdelen (2020) as $5985 \mathrm{~kg} \mathrm{ha}^{-1}$ at the same conditions. Tunali et al. (2020) examined the effects of different water levels and seed coating techniques on water use efficiency and cotton yield. Among the yield values obtained in the study, the highest cotton yield was obtained from delinted cotton seed with $6223 \mathrm{~kg} \mathrm{ha}^{-1}$ and an irrigation level of $100 \%\left(\mathrm{D}_{1}\right)$. It is seen that the above studies and the results obtained from this study are compatible. In evaluations conducted previously, it has been found that irrigation levels significantly affect seed cotton yield. It has been concluded that the most proper irrigation program suggested for achieving the highest cotton yield would be using the pan evaporation applications under sufficient water conditions in which the crop water requirements were fully met by IL$100 \%$ treatment $\left(\mathrm{D}_{1}\right)$.

Regression analysis was performed to evaluate the yield values obtained in cotton. According to the regression analysis results, a meaningful second-order polynomial relation was found between seasonal water use and cotton 
yield (Figure 1). Yazar et al. (2002a), Dagdelen et al. (2009), Erten and Dagdelen (2020), Unlu et al. (2011) examined the polynomial relationship with yield and water use in cotton irrigated by drip irrigation.

The ky factor, which shows the relationship between Relative ET and Relative yield, was determined according to Stewart et al. (1977). The yield response factor $\left(\mathrm{k}_{\mathrm{y}}\right)$ was determined to be 0.73 in gravimetric applications and 0.89 in pan evaporation applications (Figure 2). The average $\mathrm{k}_{\mathrm{y}}$ for the whole growing season was found to be 0.84 by Doorenbos and Kassam (1986), 0.89 by Yazar et al. (2002b), 0.78 by Dagdelen et al. (2009), and 0.73 to 0.82 by Tunalı et al. (2020) in Aydin conditions.

Table 4 shows the WUE and IWUE values obtained from the research during the growing season. WUE and
IWUE values decreased when the irrigation amount increased. In the study, due to the water stored in the soil, the IWUE values were higher than the WUE values (0.69 $\mathrm{kg} \mathrm{m}^{-3}\left(\mathrm{D}_{2}\right.$ - pan evaporation for IL-67\%) to $1.04 \mathrm{~kg} \mathrm{~m}^{-3}$ $\left(\mathrm{C}_{4}\right.$ - gravimetric for IL-0\%)). Treatment IL-33\% from all applications $\left(\mathrm{C}_{3}\right.$ and $\left.\mathrm{D}_{3}\right)$ used to water more efficiently. Thus, when water was restricted under these conditions, a reduction of $26.7 \%$ and $36.4 \%$ were seen in seed cotton yield. Table 6 shows a comparison of the WUE and IWUE values obtained from our study and the water efficiency values reported by other researchers. The table shows that both WUE and IWUE values were similar to the findings of other researchers.

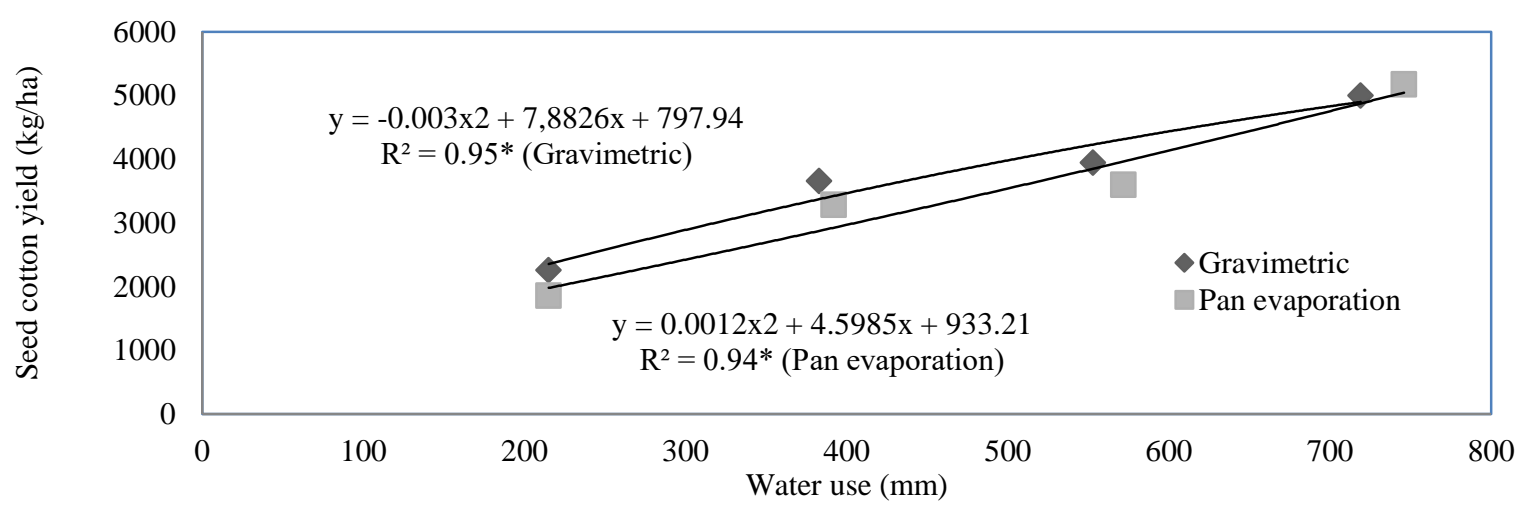

Figure 1. The relationship between water use and seed cotton yield

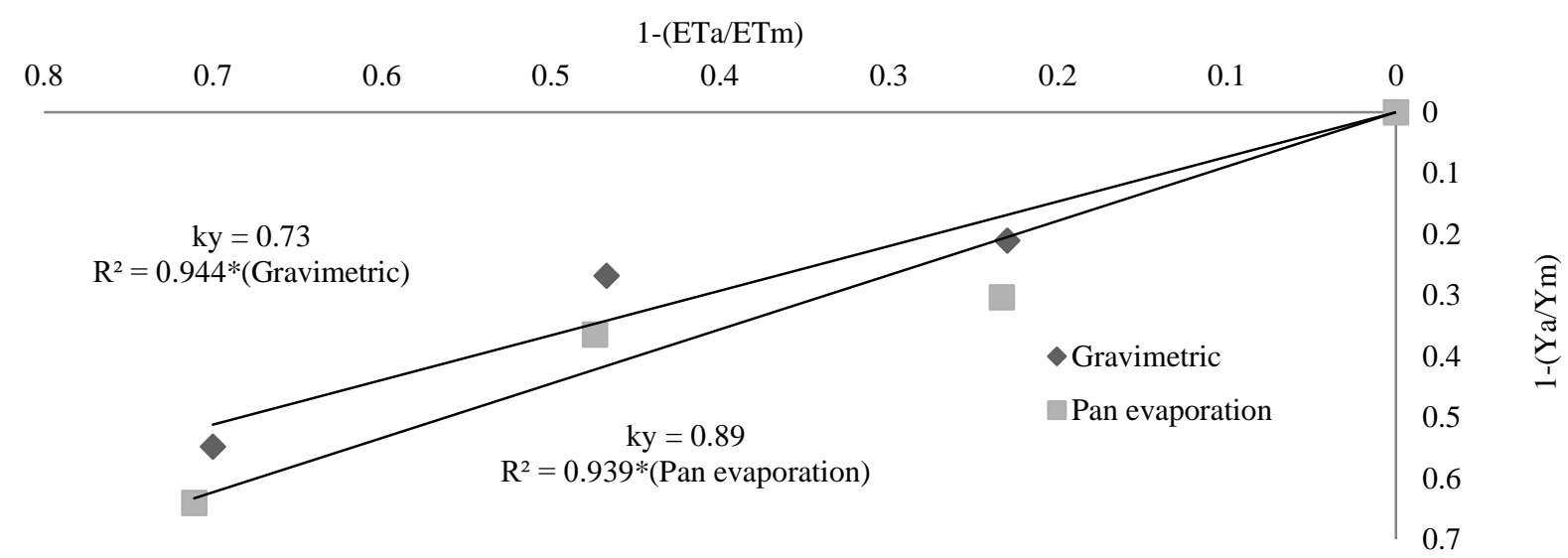

Figure 2. Yield response factor, $\mathrm{k}_{\mathrm{y}}$, of cotton seed irrigation approaches

\section{Conclusion}

When the results obtained from the study are examined, it has been revealed that both the amount of irrigation water and water application approaches and the use of water are vital in obtaining a higher yield in cotton. It was observed that irrigation levels (IL) significantly affected cotton yield at the $\mathrm{P}<0.01$ level. The highest seed cotton yield was obtained from IL-100\% treatment as averaging $5083 \mathrm{~kg}$ ha 1 , followed by IL-67\% treatment as averaging $3771 \mathrm{~kg} \mathrm{ha}$ 1. Irrigation applications had no significant effect on seed cotton yield. Moreover, pan evaporation applications with IL-100\% treatment $\left(\mathrm{D}_{1}\right)$ performed higher yields than gravimetric applications with IL- $100 \%$ treatment $\left(C_{1}\right)$. It has been found that the increase in irrigation interval leads to a decrease in WUE and IWUE values. Likewise, the highest values of WUE and IWUE were observed at the lowest irrigation levels in different irrigation applications. However, the lowest cotton yield values occurred in irrigation applications with the lowest irrigation level. Therefore, it reveals that it would be inconvenient to use low irrigation levels in Aydın Plain conditions, especially for cotton irrigated with drip irrigation. The study also concluded that there is a significant relationship between seasonal water consumption and seed cotton yield. Overall, this research indicated that pan evaporation applications 
with IL-100\% treatment $\left(\left(\mathrm{D}_{1}\right)\right.$ could be used for cotton grown in the Aegean region, similar to Turkey's area, under no water shortage. Besides, it can be said that IL$67 \%$ can be used in cotton irrigated by the gravimetric method in semi-arid climates with water constraints. Here, a $33 \%$ reduction (IL-67\%) of water delivered to the soil by drip irrigation corresponded to a $26.7 \%$ yield reduction during the growing season.

\section{References}

Acikgoz N, Aktas ME, Mokhaddam AF, Ozcan K. 1994. Tarist an Agrostatistical Package Programme for Personel Computer. Proceedings of Field Crops Symposium, Ege Univ. Fac. of Agriculture, Izmir, Turkey, 25-29 April 1994, pp. 264-267 (in Turkish with English abstract).

Akcay, S, Dagdelen, N. 2017. Water productivity and fiber quality parameters of deficit irrigated cotton in a semi-arid environment. Fresenius Environmental Bulletin, 26(11): 6500-6507

Aksoy E, Aydin G, Seferoglu S. 1998. The Important Characteristics and Classification of Soils of the Land of Agricultural Faculty, Adnan Menderes University. Proceedings of First Agricultural Conference in Aegean Region, Aydin, Turkey 7-11 September, pp. 7-11 (in Turkish with English abstract).

Anonymous, 2019a. Cotton report. T.C. Ministry of Customs and Trade, Ankara, TURKEY, pp.2-3.

Anonymous, 2019b. Climatic Report of Aydin Province, State Meteorological Organization Publications, Aydin, Turkey.

Basal, H, Dagdelen, N, Unay, A, Yilmaz, E. 2009. Effects of deficit drip irrigation ratios on cotton (Gossypium hirsutum L.) yield and fiber quality. Journal of Agronomy \& Crop Science, 195(1): 19-29.

Cetin, O, Bilgel, L. 2002. Effects of different irrigation methods on shedding and yield of cotton. Agricultural Water Management, 54: 1-15.

Colaizzi PD, Evett SR, Howell TA. 2005. Cotton Production with SDI, LEPA and Spray Irrigation in a Thermally Limited Climate. Proceedings of the Conference on Emerging Irrigation Technology. The Irrigation Association, Phoenix, Arizona, (CD ROM), 6-8 November 2005, pp. 15-30.

Dagdelen N, Yilmaz E, Sezgin F, Gurbuz T, Akcay S. 2005. Effects of Different Trickle Irrigation Regimes on Cotton (Gossypium hirsutum L.) Yield in Western Turkey. Pakistan Journal of Biological Sciences, 8(10): 1387-1391.

Dagdelen, N, Basal, H, Yilmaz, E, Gurbuz, T, Akcay, S. 2009. Different drip irrigation regimes affect cotton yield, water use efficiency and fiber quality in western Turkey. Agricultural Water Management, 96(1): 111-120.

Dagdelen, N, Gurbuz, T, Tunali, SP. 2019. Response of different cotton cultivars to water stress on water-yield relations under drip irrigation conditions in Aydin plain. Derim, 36(1): 64-72 (in Turkish with English abstract).

Dagdelen, N, Yilmaz, E, Sezgin, F, Gurbuz, T. 2006. Water-yield relation and water use efficiency of cotton (Gossypium hirsutum L.) and second crop corn (Zea mays L.) in western Turkey. Agricultural Water Management, 82: 63-85.

Doorenbos J, Kassam AH. 1986. Yield Response to Water. Irrigation and Drainage, FAO, ROME, Paper: 33, pp. 257.

Ertek A, Kanber R. 2001. Effects of Different Irrigation Programs on the Growth of Cotton Under Drip Irrigation. Turkish Journal of Agriculture and Forestry, 25: 415-425(in Turkish with English abstract).

Erten E, Dagdelen N. 2020. Yield and Water Relations of Drip Irrigated Cotton Under Various Irrigation Levels. Journal of Scientific and Engineering Research, 7(2): 204-211.
Heerman DF. 1985. ET in Irrigation Management. Proceedings of the National Conference on Advances in Evapotranspiration, Transactions of the ASAE, 16-17 December 1985, pp. 323-334.

Howell TA, Cuence RH, Solomon KH. 1990. Crop Yield Response. In: Hoffman GJ et al. (editors). Management of Farm Irrigation Systems. ASAE, St. Joseph, MI. 93-122.

Hussein F, Janat M, Yakoub A. 2011. Assessment of Yield and Water Use Efficiency of Drip-Irrigated Cotton (Gossypium hirsutum L.) as Affected by Deficit Irrigation. Turkish Journal of Agriculture and Forestry, 35: 611-621.

Ibragimov, N, Evett, SR, Esanbekov, Y, Kamilov, BS, Mirzaev, L, Lamers, JPA. 2007. Water use efficiency of irrigated cotton in Uzbekistan under drip and furrow irrigation. Agric. Water Manag., 90: 112-120.

Kanber R. 1984. Cukurova Kosullarinda Acik Su Yuzeyi Buharlasmasindan (Class A Pan) Yararlanarak Birinci Ve Ikinci Urun Yerfistiginin Sulanmasi. Tarsus: Bolge Toprak Su Arast. Enst. Mud. Yayinlari. 78(33): 1-151 (in Turkish).

Karam, F, Lahoud, R, Masaad, R, Daccache, A, Mounzer, O, Rouphael, Y. 2006. Water use and lint yield response of drip irrigated cotton to length of irrigation season. Agricultural Water Management, 85: 287-295.

Mateos, L, Berengena, J, Orgaz, F, Fereres, E. 1991. A comparison between drip and furrow irrigation in cotton at two levels of water supply. Agric. Water Manag., 19: 313324.

Panda, RK, Behera, SK, Kashyap, PS. 2004. Effective management of irrigation water for maize under stressed conditions. Agric. Water Manage., 66: 181-203.

Sezen, SM, Yazar, A, Canbolat, M, Eker, S, Celikel, G. 2004. Effect of drip irrigation management on yield and quality of field grown green beans. Agric. Water Manag., 54: 189-203.

Sezgin F, Yilmaz E, Dagdelen N, Bas S. 2001. Effect of Different Irrigation Methods and Water Supply Level Application on Water-Yield Relations in Cotton Growing. Proceedings of the Third National Hydrology Congress, 9 Eylul Univ., Izmir, Turkey, 27-29 June 2001, pp. 27-29 (in Turkish with English abstract).

Simsek M, Kacira M, Tonkaz T. 2004. The Effects of Different Drip Irrigation Regimes on Watermelon (Citrullus lanatus) Yield and Yield Components Under Semi-Arid Climatic Conditions. J. Agric. Res, 55: 1149-1157.

Stewart JL, Danielson RE, Hanks RJ, Jackson EB, Hagan RM, Pruitt WO, Franklin WT, Riley JP. 1977. Optimizing Crop Production Through Control of Water and Salinity Levels in the Soil. Logan, USA: Utah Water Lab, PRWG151-1, p 191.

Tunali SP, Gurbuz T, Dagdelen N, Yorulmaz A. 2020. The Effects of Different Drip Irrigation Levels and Seed-Coated Techniques on Yield and Water Use Efficiency of Cotton. Journal of Scientific and Engineering Research, 7(6): 62-70.

Unlu, M, Kanber, R, Koc, DL, Tekin, S, Kapur, B. 2011. Effects of deficit irrigation on the yield and yield components of drip irrigated cotton in Mediterranean environment. Agricultural Water Management, 98: 597-605.

Wang, Z, Liu, Z, Zhang, Z, Liu, X. 2009. Subsurface drip irrigation scheduling for cucumber (Cucimus sativus L.,) grown in solar greenhouse based on $20 \mathrm{~cm}$ standard pan evaporation in Northeast China. Scientia Horticulturae, 123: 51-57

Yazar, A, Sezen, SM, Gencel, B. 2002a. Drip irrigation of corn in the Southeast Anatolia Project (GAP) area in Turkey. Irrigation and Drainage, 51: 293-300.

Yazar, A, Sezen, SM, Sesveren, S. 2002b. Lepa and trickle irrigation of cotton in the Southeast Anatolia Project (GAP) Area in Turkey. Agricultural Water Management, 54(3): 189203. 